\title{
Staphylococcus aureus Detection in the Mouth of Housekeepers
}

\author{
Elaine Drehmer de Almeida Cruz ${ }^{1}$ \\ Fabiana Cristina Pimenta ${ }^{2}$ \\ Miyeko Hayashida ${ }^{3}$ \\ Marina Eidt ${ }^{4}$ \\ Elucir $\mathrm{Gir}^{5}$
}

This study assessed the prevalence of colonization by Staphylococcus aureus in hospital housekeepers, and their knowledge and beliefs regarding this problem. Three saliva samples were collected and a questionnaire regarding knowledge and beliefs was applied. Of the 92 workers, 63 (68.5\%) participated in the study; 20 were not and 43 were colonized; 13 by methicillin resistant Staphylococcus aureus and 30 by methicillin sensitive Staphylococcus aureus. Persistent carrier status of methicillin resistant Staphylococcus aureus was detected in $15.4 \%$ of cases. Low knowledge and perception of occupational risk were observed. The mouth was identified as an important reservoir of methicillin resistant Staphylococcus aureus. Analyzing knowledge and beliefs, as well as the state of carrier, is an important strategy to be added to educational actions for the prevention of workers' colonization.

Descriptors: Staphylococcus aureus; Methicillin Resistance; Health Knowledge, Attitudes, Practice; Occupational Risks.

\footnotetext{
${ }^{1}$ RN, Ph.D. in Nursing, Adjunct Professor, Departamento de Enfermagem, Universidade Federal do Paraná, PR, Brazil. E-mail: elainedrehmer@yahoo.com.br.

2 Pharmaceutical, Ph.D. in Sciences, Adjunct Professor, Instituto de Patologia Tropical e Saúde Publica, Universidade Federal de Goiás, Goiânia, GO, Brazil. Centers for Disease Control and Prevention, Atlanta, United States. E-mail: pimentaf@hotmail.com.

${ }^{3}$ RN, Ph.D. in Nursing, Escola de Enfermagem de Ribeirão Preto, Universidade de São Paulo, WHO Collaborating Centre for Nursing Research Development, SP, Brazil. E-mail: miyeko@eerp.usp.br.

${ }^{4}$ Pharmaceutical, Universidade Federal de Goiás, GO, Brazil. Email: marina.eidt@uol.com.br.

${ }^{5}$ RN, Ph.D. in Nursing, Full Professor, Escola de Enfermagem de Ribeirão Preto, Universidade de São Paulo, WHO Collaborating Centre for Nursing Research Development, SP, Brazil. E-mail: egir@eerp.usp.br.
}

Corresponding Author:

Elaine Drehmer de Almeida Cruz

Universidade Federal do Paraná. Departamento de Enfermagem.

Rua Padre Camargo, 120

Bairro Alto da Glória

CEP: 80060-240 Curitiba, PR, Brasil

E-mail: elainedrehmer@yahoo.com.br 


\title{
Detecção de Staphylococcus aureus na boca de trabalhadores da limpeza hospitalar
}

Este estudo avaliou a prevalência da colonização por Staphylococcus aureus em trabalhadores de limpeza hospitalar, e seu conhecimento e crenças acerca da problemática. Foram coletadas três amostras de saliva e aplicado questionário referente ao conhecimento e crenças. De 92 trabalhadores, 63 (68,5\%) participaram do estudo; 20 apresentaramse não colonizados e 43 colonizados; 13 para Staphylococcus aureus resistente à meticilina e 30 para Staphylococcus aureus sensível à meticilina. O estado de carreador persistente por Staphylococcus aureus, resistente à meticilina, foi detectado em 15,4\% dos casos. Baixo conhecimento e percepção do risco ocupacional foram observados. A boca foi identificada como importante reservatório de Staphylococcus aureus resistente à meticilina. Analisar o conhecimento e crenças, juntamente à investigação do estado de carreador, é importante estratégia a ser agregada às ações educativas para a prevenção da colonização de trabalhadores.

Descritores: Staphylococcus aureus; Resistência à Meticilina; Conhecimentos, Atitudes e Práticas em Saúde; Riscos Ocupacionais.

\section{Detección de Staphylococcus aureus en la boca de trabajadores de la limpieza hospitalaria}

\begin{abstract}
Este estudio evaluó la prevalencia de la colonización por Staphylococcus aureus en trabajadores de limpieza hospitalaria, y su conocimiento y creencias acerca de la problemática. Fueron recolectadas tres muestras de saliva y aplicado un cuestionario referente al conocimiento y creencias. De 92 trabajadores, 63 (68,5\%) participaron del estudio; 20 se presentaron no colonizados y 43 colonizados; 13 para Staphylococcus aureus resistente a la meticilina y 30 para Staphylococcus aureus sensibles a la meticilina. El estado de portador persistente por Staphylococcus aureus resistente a la meticilina fue detectado en $15,4 \%$ de los casos. Bajo conocimiento y percepción del riesgo ocupacional fueron observados. La boca fue identificada como importante reservatorio de Staphylococcus aureus resistente a la meticilina. Analizar el conocimiento y creencias juntamente con la investigación del estado de portador es una importante estrategia a ser agregada a las acciones educativas para la prevención de la colonización de trabajadores.
\end{abstract}

Descriptores: Staphylococcus aureus; Resistencia a la Meticilina; Conocimientos, Actitudes y Práctica en Salud; Riesgos Laborales.

\section{Introduction}

One important factor in the epidemiology of infection and colonization cases by methicillinresistant Staphylococcus aureus (MRSA) in the health care environment is workers' physical proximity with colonized or infected patients and their environment. This approximation contributes to professionals' colonization, who become potential reservoirs and disseminators of these bacteria, contributing to their dispersion in the environment and person-to-person ${ }^{(1-2)}$, besides the fact that MRSA colonization predicts infection(3). In this context, not only hospitalized and colonized individuals can show greater risk of developing MRSA infection, but also non-hospitalized people, whether health service workers or not, according to their health conditions.

Given the possible dispersion and survival of methicillin-sensitive Staphylococcus aureus (MSSA) and MRSA in the environment ${ }^{(4-5)}$ and the nature of their work, hospital housekeepers can also be colonized, 
few studies have investigated this category. This risk is aggravated by their lack of technical preparation and knowledge to perform their functions in the hospital environment ${ }^{(6)}$. This affects their risk perception and adherence to prevention measures.

The most studied anatomical sites in Staphylococcus aureus and mainly MRSA research are the nasal mucosa and skin, although the mouth has also been studied(7-9). Although Staphylococus aureus are not part of the oral cavity microbiota(10), genetically identical MRSA have been isolated from the anterior nostrils and tongue of 20 previously colonized patients, suggesting transference from the nasopharynx to the tongue ${ }^{(7)}$.

This research investigated the prevalence of colonization by MRSA and MSSA, knowledge and beliefs associated with the problem among hospital housekeepers.

\section{Methods}

\section{Study population}

This study was carried out between April 2006 and June 2008, involving housekeepers from a university hospital in the South of Brazil, after approval by the institutional review board. Out of 92 workers, 63 $(68.5 \%)$ participated in the research because they formally consented and complied with the inclusion criteria: cleaning the environment and utensils at hospital care units for adults patients, collecting three saliva samples at three-month intervals and answering questions through an individual interview. Research subjects working at the institution at the end of the study were collectively and individually informed about the results, and also about the institutional routine for the decolonization of workers colonized by MRSA.

Subjects were considered transitory carriers if only one of the three cultures was positive for $S$. aureus (carrier index $\leq 0.5$ ); persistent carrier when two or three cultures were positive (carrier index $>0.5)^{(11)}$ and with the same susceptibility pattern to the antimicrobials that were test: or non carrier when the three cultures were negative (carrier index $=0$ ).

\section{Demographic data collection, processing and analysis}

Through a confidential interview, demographic data, knowledge and occupation risk perception about MRSA were collected. Perception questions were based on the
Health Beliefs model ${ }^{(12)}$ to investigate the susceptibility and severity of colonization, benefits and barriers for the adoption of preventive measures. Answers to the closed questions were inserted in a double-entry database and data were organized and processed in EPI-Info. Answers to the open questions were submitted to quantitative discourse analysis ${ }^{(13)}$. After the answers had been listed, they were reread, grouped according to similarity and regrouped into categories, based on which the frequency rates were obtained for the characteristics repeated in the answers' contents.

\section{Laboratory data collection, processing and analysis}

Three saliva samples were obtained from each participant at three-month intervals. The samples were collected in 12-mL plastic tubes that were sterile and sent to the laboratory. The saliva was grown in mannitol salt agar plates, using the drop technique, and incubated at $370 \mathrm{C}$ for up to 48 hours. Typical colonies of staphylococcus were counted to define the colonyforming units (CFU); S. aureus was identified through the catalase, coagulase, lecithinase, DNase production and mannitol fermentation tests. The isolated colonies were determined by the disk diffusion method, in accordance with recommendations by the Clinical and Laboratory Standards Institute ${ }^{(14)}$. The following antimicrobials were used: oxacillin, cefoxitin, penicillin, erythromycin, itromycin, clindamycin, tetracycline, riphampicin, cyprofloxacin, gentamycin, trimethropim sulfametoxazole, vancomycin, linezolid and mupirocin (Oxoid-Basingstoke, England). ATCC strains of S. aureus 25923 and $29213^{(14)}$ were used for quality control purposes. The data were processed in EPI-Info and analyzed by descriptive statistics.

\section{Results}

The 63 housekeepers who participated in the study were all women, between 21 and 56 years old, with an average age of 38.8 years and standard deviation of 6.9. Work time ranged from 3 to 240 months, with a median 19.1 months. As for the work shift, 59 (93.7\%) worked during the day and only 1 (1.6\%) informed working at another hospital institution. The characterization of colonized and non-colonized housekeepers and their respective demographic variables are shown in Table 1. The variable "not informed" referred to the subject's refusal to answer the question. 
Table 1 - Characterization of housekeepers at a large public hospital according to colonization by Staphylococcus aureus, Curitiba, 2006-8

\begin{tabular}{|c|c|c|c|c|c|c|}
\hline \multirow[t]{2}{*}{ Variables } & \multicolumn{2}{|c|}{$\begin{array}{c}\text { Colonized } \\
(n=43)\end{array}$} & \multicolumn{2}{|c|}{$\begin{array}{l}\text { Not colonized } \\
(n=20)\end{array}$} & \multicolumn{2}{|c|}{$\begin{array}{c}\text { Total } \\
(n=63)\end{array}$} \\
\hline & $f$ & $\%$ & $f$ & $\%$ & $f$ & $\%$ \\
\hline \multicolumn{7}{|l|}{ Age (years) } \\
\hline 21 to 29 & 04 & 9.3 & 01 & 5.0 & 05 & 7.9 \\
\hline 30 to 39 & 17 & 39.5 & 09 & 45.0 & 26 & 41.3 \\
\hline 40 to 49 & 19 & 44.2 & 09 & 45.0 & 28 & 44.4 \\
\hline$\geq 50$ & 03 & 7.0 & - & - & 03 & 4.8 \\
\hline Not informed & - & - & 01 & 5.0 & 01 & 1.6 \\
\hline \multicolumn{7}{|c|}{ Work time (months) } \\
\hline 03 to 11 & 13 & 30.2 & 03 & 15.0 & 16 & 25.4 \\
\hline 12 to 23 & 08 & 18.6 & 09 & 45.0 & 17 & 27.0 \\
\hline 24 to 35 & 16 & 37.2 & 03 & 15.0 & 19 & 30.2 \\
\hline$\geq 36$ & 06 & 14.0 & 04 & 20.0 & 10 & 15.9 \\
\hline Not informed & - & - & 01 & 5.0 & 01 & 1.5 \\
\hline \multicolumn{7}{|l|}{ Shift } \\
\hline Day & 40 & 93.0 & 19 & 95.0 & 59 & 93.7 \\
\hline Night & 01 & 7.0 & 01 & 5.0 & 04 & 6.3 \\
\hline \multicolumn{7}{|c|}{ Works at another hospital } \\
\hline Yes & 01 & 2.3 & - & - & 01 & 1.6 \\
\hline No & 40 & 93.0 & 18 & 90.0 & 58 & 92.1 \\
\hline Not informed & 02 & 4.7 & 02 & 10.0 & 04 & 6.3 \\
\hline
\end{tabular}

In total, 189 saliva samples were collected and processed from 63 housekeepers. S. aureus was isolated in 68 samples (36.0\%) of 43 subjects. Bacterial counts ranged between 40 and $40,000 \mathrm{cfu} / \mathrm{mL}$.

The prevalence of housekeepers who were noncarriers of $S$. aureus in the mouth was $31.7 \%$ (20/63), against $68.2 \%(43 / 63)$ for carriers. Among the 43 carriers, 29 (67.4\%) were considered transitory and 14 (32.6\%) persistent for S. aureus.

The prevalence of MSSA among the research subjects was $47.6 \%(30 / 63)$; the prevalence of MRSA was $20.6 \%$ (13/63). Among the 13 MRSA carriers, two (15.4\%) were considered persistent and $11(84.6 \%)$ transitory.

The characteristics of the 13 housekeepers colonized by MRSA with regard to work unit, age, work time at the institution and work at another hospital are shown in Table 2.

Table 2 - Characterization of 13 housekeepers at a large public hospital colonized by methicillin resistant Staphylococcus aureus (MRSA), Curitiba, 2006-8

\begin{tabular}{|c|c|c|c|c|}
\hline Subject & Age (years) & Work time at institution (months) & Work unit & Works at another hospital \\
\hline 1c & 37 & 18 & Neurology & No \\
\hline $2 c$ & 42 & 24 & Maintenance & No \\
\hline $3 c$ & 44 & 24 & Infectology & No \\
\hline $4 c$ & 36 & 07 & Otorhino/ophthalmo & No \\
\hline $5 c$ & 41 & 120 & Otorhino/ophthalmo & No \\
\hline $6 c$ & 36 & 25 & Medical clinic & No \\
\hline 7c & 26 & 28 & Medical clinic & No \\
\hline $8 c$ & 50 & 12 & Obstetrics & No \\
\hline $9 c$ & 48 & 22 & Nephrology & No \\
\hline $10 c$ & 43 & 08 & Nephrology & No \\
\hline $11 \mathrm{c}$ & 26 & 32 & Intensive care & Not informed \\
\hline $12 c$ & 42 & 31 & Intensive care & No \\
\hline $13 c$ & 25 & 05 & Emergency care & No \\
\hline
\end{tabular}

The age of the research subjects colonized by MRSA ranged from 25 to 50 years and the work time at the institution from 5 to 120 months. Two subjects worked at the Intensive Care Unit, two at the Medical Clinic, two at the Nephrology and two at the Otorhinolaryngology and Ophthalmology Unit. One colonized professional was identified at the other units. None of the participants mentioned a second job and one refused to answer the question.

Only $12.7 \%(8 / 63)$ of the housekeepers mentioned knowledge about MRSA and prevention measures; the only informed knowledge source was professional practice. With regard to MRSA colonization prevention measures, 37 (58.7\%) affirmed they did not know about these; the 26 workers who mentioned they knew them indicated the following essential prevention measures: use of individual protection equipment (IPE) $(81.4 \%)$; hand washing (11.4\%); adequate behavior (4.3\%) and the adoption of isolation measures (2.9\%). Only $29(46 \%)$ subjects related IPE use with occupational exposure prevention. The influence of colleagues behavior who do not adopt safety measures on the other professionals' behavior was investigated, and 47 $(74.6 \%)$ affirmed that this attitude does not interfere in 
individual behavior, while $26(41.3 \%)$ answered that it interferes and one did not answer.

When investigating the workers' beliefs on susceptibility to MRSA colonization, 44 (70\%) mentioned believing that the risk exists, while 19 (30\%) could not give this information. The 'colonized' status affects the work team and their relatives, patients and their own health, in the subjects' perception. Unfavorable work conditions were indicated as the main barriers against the adoption of prevention measures, such as lack of IPE and insufficient numbers of workers.

\section{Discussion}

This is the first report on MRSA in the saliva of hospital housekeepers in Brazil. The research is relevant in view of the occupational risk, the fact that the status of MRSA carrier is a predictive factor of infection and potential dissemination and because mostly lay workers are involved with regard to microbiology principles, transmission mechanisms and infection prevention measures associated with health care services. Their importance for Nursing relates to the fact that they are frequently hired by outsourced services and led by nurses. The obtained results contribute to the acknowledgement of the colonization problem, as this condition affects the workers and service users' health, and contribute to the planning of control and prevention actions.

The prevalence level of $20.6 \%$ was high as these are healthy people, even if they work in a hospital environment. Although most studies investigate MRSA prevalence in nasal mucosa and skin, some studies have looked at the mouth to investigate $S$. aureus ${ }^{(7-9)}$. Its relevance is related with the fact that, while talking, countless MRSA-contaminated saliva droplets can be disseminated into the environment and from person-toperson, evidencing the risk of workers becoming colonized with MRSA in the mouth and, thus, disseminating it to patients, the health care environment and the community. The dissemination risk is also related to the persistent or transitory nature of the colonization. A twoyear follow-up study evidenced the transitory nature of S. aureus colonization in $28(41.8 \%)$ out of 67 research subjects $^{(11)}$. Although the present study results reveal the condition of transitory S. aureus carrier (67.4\%) as the most frequent, including MRSA (84.6\%), reports exist $^{(15)}$ that transitorily colonized workers can become persistent carriers in case of skin injuries, potentiating transmission risks.

A research of approximately 15,000 patients showed that MRSA infections diagnosed in the community were significantly associated with higher mortality rates when compared with the absence of this agent as an infection cause $^{(16)}$. Hence, one cannot ignore the meaning of MRSA colonization for workers' health, including housekeepers. In that sense, knowledge on the carrier status, especially when persistent, and institutional policies for decolonization contribute to reduce MRSA dissemination and death risk in case of infection.

Workers' persistent MRSA colonization should be included as an occupational event and supported by labor legislation. Prevalence rates of methicillin resistance higher than $40 \%$ are observed in S. aureus isolated from hospital infections in Southern and Eastern Europe ${ }^{(17)}$. Rates of $31 \%$ in $S$. aureus isolated from patients with skin and soft tissue infection were reported in Latin America(18), reaching approximately $65 \%$ at Intensive Care Units in North American hospitals ${ }^{(19)}$. It should be highlighted, however, that these data refer to individuals with infection.

A research of 340 healthy health professionals in São Paulo State showed a prevalence level of $47.6 \%$ of subjects colonized with $S$. aureus and $4.1 \%$ for $\operatorname{MRSA}^{(20)}$. In the present study, the prevalence level of MRSA identified among hospital housekeepers was $20.6 \%$.

With regard to this professional category, they are not sufficiently prepared to work at an unhealthy service involving, among others, biological risks. They lack elementary technical knowledge regarding microorganism transmission mechanisms and hygiene in hospital environments. Although most of them start working at the hospital without training, investing in education results in knowledge gains, which is a possible factor in infection prevention, according to researchers $^{(6)}$.

It is highlighted that research involving hospital housekeepers ${ }^{(6,21-22)}$ contributes to increase the visibility of different related problems and encourages experts to seek, based on scientific evidence, new guidelines with a view to greater safety and quality in their professional performance.

This research revealed that the research subjects receive only occasional orientations from clinical nurses and the hospital infection control service team. They obviously consider their professional qualification of little importance, based on the study results that revealed the low education level of workers hired in hospital services ${ }^{(21)}$. The association between the low education level and lack of technical knowledge to work in an unhealthy environment enhances occupational risks. Although these workers do not have direct contact with patients, they are 
exposed to the high load of environmental contaminants and to the risk of colonization, similarly to professionals in direct contact with patients.

In this study, only $12.7 \%$ indicated knowledge on MRSA and $58.7 \%$ did not know the measures to prevent its dissemination. These results were considered the main factor that is potentially associated with the high prevalence of MRSA colonization. Brazilian legislation recommends that hospital housekeepers be trained to use IPE, prevent biological risk and observe the principles of personal hygiene(23). Knowledge is acknowledged as essential to prevent MRSA colonization, although it does not determine by itself workers' behavior in daily professional reality. In this sense, the characterization of the workers' health beliefs regarding this problem can help to identify and understand risk attitudes and contribute to outline prevention strategies. One third of the research subjects did not recognize the colonization risk, underestimating their own risk. Greater perception of vulnerability to risks can be a strategy for the adoption of safe practices ${ }^{(24)}$. A study developed in one American state assessed health professionals' perceptions and knowledge on hospital infection prevention practices, based on the Health Beliefs Model, revealed limited knowledge on hand washing and non-identification of barriers to prevent hospital infection. The results contributed to the construction and review of specific protocols regarding this theme ${ }^{(25)}$.

The fact that the workers know their colonization condition or MRSA prevalence in their work group can be a motivating elements for educative measures as well as to adopt safe attitudes. In Brazil, no public guideline exists for the decolonization of workers who are MRSA carriers, so that institutions are responsible for determining criteria and their own protocol.

\section{Conclusion}

Through microbiological saliva analysis, Staphylococcus aureus could be detected in the mouth. This condition can entail risks for workers' health, environmental and person-to-person dissemination. Hospital housekeepers can be MRSA carriers and disseminators to the environment and potentially to the team and patients, as the study results show colonization prevalence rates of $20.6 \%$. As the carrier status is a predictive factor of infection, knowing the condition of MRSA carrier is the workers' right and permits reflecting on their practice and even on the decolonization decision, in accordance with the institutional protocol. As such, it is useful to change attitudes and achieve greater adherence to prevention measures.

Low knowledge and colonization risk perception levels in view of MRSA prevalence rates among housekeepers appoint the need to plan educative interventions to prevent colonization. Nurses are directly involved in this problem because they frequently lead and command these workers.

Considering that behavior depends on knowledge and beliefs attributed to prevention measures, this study contributes to a better understanding of the context of MRSA colonization. Moreover, it aroused reflections on possible colonization in the workers' mouth and highlighted the need to value this theme in health education actions for hospital housekeepers, promoting knowledge and encouraging risk prevention actions.

\section{References}

1. Albrich WC, Harbarth S. Health-care worker: source, vector, or victim of MRSA? Lancet Infect Dis. 2008; 8(5):289-301.

2. Cookson B, Peters B, Webster M, Phillips I, Rahman M, Noble W. Staff carriage of epidemic methicillinresistant Staphylococcus aureus. Clin Microbiol. 1989; 27(7):1471-6.

3. Goud IM. The clinical significance of methicillinresistant Staphylococcus aureus. J Hosp Infect. 2005; 61(4):277-82.

4. Kramer A, Schwebke I, Kampf G. How long do nosocomial pathogens persist on inanimate surfaces? A systematic review. BMC Infect Dis. [internet]. 2006 [acesso: 12 jun 2008]: 6:130. Disponível em: http:// www.pubmedcentral.nih.gov/articlerender.fcgi?tool=pu bmed\&pubmedid $=16914034$

5. Sexton T, Clarke P, O'Neill E, Dilane T, Humphreys $\mathrm{H}$. Environmental reservoirs of methicillin-resistant Staphylococcus aureus in isolation rooms: correlation with patients isolates and implications for hospital hygiene. J Hosp Infect. 2006;62(2):187-94.

6. Demirturk N, Demirdal T. Effect of a training program for hospital cleaning staff on prevention of hospitalacquired infection. Infect Control Hosp Epidemiol. 2006;27(12):1410-1.

7. Small H, Casey AL, Elliott TS, Rollason J, Hilton AC, Ball S. The oral cavity: an overlooked site for MRSA screening and subsequent decolonization therapy? J Infect. 2007;55(4):378-9. 
8. Smith AJ, Brewer A, Kirkpatrick P, Jackson MS, Young

J, Watson $S$ et al. Staphylococcus aureus in the oral cavity from the patients in a regional burns unit. J Hosp Infect. 2003;55(3):184-9.

9. Smith AJ, Robertson D, Tang MK, Jackson MS, MacKenzie D, Bagg J. Staphylococcus aureus in the oral cavity: a three-year retrospective analysis of clinical laboratory data. Br Dent J. 2003;195(12):701-3.

10. Smith, AJ, Jackson, M, Bagg, J. The ecology of Staphylococcus species in the oral cavity. J Med Microbiol 2001;50(11):940-6.

11. Nilsson P, Ripa T. Staphylocccus aureus throat colonization is more frequent than colonization in the anterior nares. J Clin Microbiol. 2006;44(9):3334-9.

12. Rosenstock IM. The health belief model and preventive health behaviors. Health Educ Monogr. 1974;2(4):304-87.

13. Bardin L. Análise de conteúdo. Lisboa: Edições 70; 1977.

14. Clinical and Laboratory Standards Institute/LCCLS. Performance Standards for Antimicrobial Susceptibility Testing; Fifteenth Informational Supplement. Wayne (PA): CLSI/NCCLS; 2005.

15. Ben-David D, Mermel LA, Parenteau S. Methicillinresistant Staphylococcus aureus transmission: the possible importance of unrecognized health care worker carriage. Am J Infect Control. 2008;36(2):93-7.

16. Delaney JAC, Schneider-Lindner $V$, Brassard $P$, Suissa S. Mortality after infection with methicillinresistant Staphylococcus aureus (MRSA) diagnosed in the community. BMC Med [internet]. 2008 [acesso 12 jun 2008]; 6(2). Disponível em: http://www. ncbi.nlm.nih.gov/pubmed/18234115 ?ordinalpos= 1\&itool=EntrezSystem2.PEntrezPubmed.Pubmed_ ResultsPanel.Pubmed_DefaultReportPanel.Pubmed_ RVDocSum\&log \$=freejrpmc- 10.1186/1741-7015-6-2

17. Tiemarsma EW, Bronzwaer SL, Lyytikäinen $\mathrm{O}$, Degener JE, Schrijnemakers $\mathrm{P}$, Bruinsma $\mathrm{N}$ et al. Methicillin-resistant Staphylococcus aureus in Europe, 1999-2002. Emerg Infec Dis. 2004;10(9):1627-34.

18. Gales AC, Jones RN, Pfaller MA, Gordon KA, Sader HS. Two-year assessment of the pathogen frequency and antimicrobial resistance patterns among organisms isolated from skin and soft tissue infections in Latin America hospitals: results from the SENTRY antimicrobial surveillance program, 1997-98. SENTRY Study Group. Int J Infect Dis. 2000;4(2):75-84.

19. Klevens RM, Edwards JR, Tenover FC, McDonald LC, Horan T, Gaynes R et al. Changes in the epidemiology of methicillin-resistant Staphylococcus aureus in intensive care units in U.S. hospitals, 1992-2003. Clin Infect Dis. $2006 ; 42(3): 389-91$.

20. Carvalho MJ, Pimenta FC, Hayashida M, Gir E, Silva AM, Barbosa CP et al. Prevalence of methicillinresistant and methicillin-susceptible $S$. aureus in the saliva of health professionals. Clinics. (São Paulo) 2009;64(4):295-305.

21. Chillida MSP, Cocco MIM. Saúde do trabalhador \& terceirização: perfil de trabalhadores de serviço de limpeza hospitalar. Rev. Latino-Am. Enfermagem [periódico na Internet]. $2004 \mathrm{Abr}$ [acesso 02 set 2009]; 12(2): 271-276. Disponível em: http://www. scielo.br/scielo.php?script $=$ sci_arttext\&pid $=$ S0104$11692004000200018 \&$ Ing $=$ pt. doi: 10.1590/S010411692004000200018.

22. Monteiro MI, Chillida MSP, Bargas EB. Educação continuada em um serviço terceirizado de limpeza de um hospital universitário. Rev. Latino-Am. Enfermagem. [periódico na Internet]. 2004 [acesso em 0209 2009 02]; 12(3):541-8. Disponível em: http://www. scielo.br/scielo.php?script $=$ sci_arttext\&pid $=$ S010411692004000300013\&lng=pt. doi: 10.1590/S010411692004000300013.

23. Ministério do Trabalho e Emprego (BR). Portaria n.485 de 11 de novembro de 2005. Dispõe sobre a Norma Reguladora NR32 relativa à segurança e saúde no trabalho em serviços de saúde. Diário Oficial da União 2005; seção 1, 16 jun.

24. Canini SRMS, Gir E, Hayashida M, Machado AA. Acidentes perfurocortantes entre trabalhadores de enfermagem de um hospital universitário do interior paulista. Rev. Latino-Am. Enfermagem [periódico na Internet]. Abr 2002. [acesso em 02 set 2009]; 10(2):172-8. Disponível em: http://www.scielo. br/scielo.php?script=sci_arttext\&pid=S010411692002000200008\&lng=pt. doi: 10.1590/S010411692002000200008.

25. Lewis $\mathrm{KL}$, Thompson JM. Health care professionals' perceptions and knowledge of infection control practices in a community hospital. Health Care Manag. $2009 ; 28(3): 230-8$.
Received: Sep. 21 2009

Accepted: Ago. $25^{\text {th }} 2010$ 